\title{
Organization of the Epstein-Barr Virus DNA Molecule
}

\section{Fine Mapping of the Boundaries of the Internal Repeat Cluster of B95-8 and Identification of Additional Small Tandem Repeats Adjacent to the HR-1 Deletion}

\author{
S. DIANE HAYWARD, ${ }^{1 *}$ SONDRA G. LAZAROWITZ, ${ }^{2}$ AND GARY S. HAYWARD ${ }^{1}$ \\ Department of Pharmacology and Experimental Therapeutics ${ }^{1}$ and Department of Molecular Biology and \\ Genetics, ${ }^{2}$ The Johns Hopkins University School of Medicine, Baltimore, Maryland 21205
}

Received 27 October 1981/Accepted 16 March 1982

\begin{abstract}
We used cloned BamHI fragments from Epstein-Barr virus strain B95-8 [EBV(B95-8)] DNA to obtain detailed restriction maps of the region of the genome adjacent to the large internal repeat cluster. These maps together with the results of hybridization experiments using a 3.1-kilobase repeat probe defined more precisely the location of the junctions between the internal repeat cluster and the flanking unique-sequence DNA. On one side $\left(\mathrm{U}_{\mathrm{L}}\right)$, the repeat sequences extended $600 \pm 80$ base pairs (bp) into BamHI-Y; on the other side $\left(U_{S}\right)$, they extended $1,300 \pm 200$ bp into BamHI-C. Therefore, EBV(B95-8) DNA contained a nonintegral number of 3.1-kilobase repeat units, namely, 12.6 copies. The mapping studies also revealed a second series of internal tandem repetitions in EBV(B95-8) DNA located within the BamHI-H fragment. This cluster comprised 11 copies of a 135-bp repeat unit which contained a single site for the Not I restriction endonuclease. Hybridization to these cloned EBV(B95-8) fragments using total EBV(HR-1) DNA as probe indicated that the deletion in EBV(HR-1) removed all 3,000 bp of unique-sequence DNA which lay between the large 3.1kilobase and the small 135-bp repeat clusters. Thus, the deletion which destroyed the transforming ability in the EBV(HR-1) virus was bounded on either side by tandem repetitions.
\end{abstract}

Information has been steadily accumulating on the structure of the Epstein-Barr virus (EBV) DNA molecule. The linear DNA isolated from virions varies in molecular weight from $110 \times$ $10^{6}$ to $120 \times 10^{6}$, depending on the isolate $(2,10$, $12,17)$. The DNA molecule contains a number of repetitive elements. The termini consist of a series of tandem repeats of a 500-base pair (bp) sequence $(9,16)$, and a cluster of tandem repetitions of a 3.1-kilobase $(\mathrm{kb})$ sequence located between 0.710 and 0.915 map units divides the DNA molecule into large unique $\left(U_{\mathrm{L}}\right)$ and short unique $\left(U_{S}\right)$ segments $(4,8,10)$. Although all isolates so far studied adhere to this general structural pattern, sufficient variations occur within the genome to render each isolate individually distinguishable. Variations in size occur most frequently in restriction fragments encompassing the 3.1-kb repeat unit cluster which may comprise anywhere from 3 to 6 (HR-1) up to 12 (B95-8) copies of the repeats and in the region of the EcoRI-C fragment (0.065 to 0.166) which sustains its largest deletion (approximately $8 \times$ $10^{6}$ molecular weight) in B95-8 DNA $(2,5,6,10$, $12,17,20,21,25)$. Smaller insertions and deletions have also been noted in other regions of the genome (2).
EBV transforms human and simian lymphocytes in vitro into continuously growing lymphoblastoid cell lines. The single exception is the nontransforming HR-1 isolate. A characteristic deletion in the genome of HR-1 appears to correlate with the inability of this isolate to transform lymphocytes. Superinfection of nonproducer EBV cell lines, such as Raji, with HR1 virus can result in the regeneration of transforming virus. Analysis of the DNA of these new viruses indicates that in each case they represent recombinant molecules in which the sequences deleted in HR-1 DNA have been regained from the resident Raji genomes (7). The HR-1 deletion was initially described in general terms by RaabTraub et al. (18) and defined in more detail by Bornkamm et al. $(2,5)$ and Heller et al. (12) and is located near coordinates 0.7 in the $U_{\mathrm{L}}$ region, adjacent to the $3.1-\mathrm{kb}$ internal repeats.

In this paper, we describe the use of cloned fragments of B95-8 DNA to construct detailed restriction maps of the region surrounding the $3.1-\mathrm{kb}$ repeat cluster. These mapping data were accumulated with the aim of pinpointing (i) the location of the junctions of the 3.1-kb repeat cluster within the $U_{L}$ and $U_{S}$ segments and (ii) the location of the deletion in HR-1 DNA. These 
TABLE 1. Characteristics of the BamHI recombinant plasmids

\begin{tabular}{llcc}
\hline $\begin{array}{c}\text { Plas- } \\
\text { mid }\end{array}$ & Fragment & $\begin{array}{c}\text { Orienta- } \\
\text { tion }^{a} \text { and } \\
\text { insert size } \\
(\mathrm{kb})\end{array}$ & Map coordinates $^{a}$ \\
\hline pSL3 & BamHI-Y & I, 1.85 & $0.686-0.696$ \\
pSL8 & BamHI-YW & I, 4.95 & $0.686-0.704$ \\
pSL9 & BamHI-W & P, 3.1 & $(0.696-0.913) / 12$ \\
pSL76 & BamHI-WW & P, 6.2 & $(0.696-0.913) / 6$ \\
pSL77 & BamHI-H & P, 5.8 & $0.652-0.686$ \\
pSL93 & BamHI-C & P, 8.9 & $0.913-0.967$ \\
\hline
\end{tabular}

$a$ The prototype (P) and inverted (I) orientations and fractional map units are both based on our standard map of the EBV(B95-8) genome drawn with the S segment on the right (10).

studies led to the discovery that B95-8 DNA contains a nonintegral number of $3.1-\mathrm{kb}$ repeat units and to the identification of a new cluster of internal tandem repeat sequences which map within the BamHI-H fragment.

(Most of this work was presented at the Fifth Cold Spring Harbor Herpesvirus Meeting, 26-31 August 1980, Cold Spring Harbor, N.Y.)

\section{MATERIALS AND METHODS}

Generation of plasmid clones of B95-8 DNA. Portions of B95-8 DNA $(1 \mu \mathrm{g})$ which had been extracted from purified virions were cleaved with the $B a m H I$ restriction endonuclease and cloned into the BamHI site of the plasmid pBR322, using the shotgun approach. Recombinant plasmids were transfected into Escherichia coli HB101 by the calcium shock method. All ampicillin-positive, tetracycline-negative colonies were grown as minicultures $(1 \mathrm{ml})$, the DNA was extracted by the method of Birnboim and Doly (1), and the size of the EBV DNA insert was estimated by electrophoresis through $1 \%$ agarose slab gels, followed by ethidium bromide staining. Recombinant plasmids carrying the BamHI-C, BamHI-W, and BamHI-Y inserts were initially identified by their ability to hybridize to an isolated $B g I I I$ repeat fragment probe. Subsequently, the identity of these plasmids and of the BamHI-H recombinant plasmid was confirmed by hybridizing the in vitro-labeled plasmid DNAs to blots of EcoRI- and HindIII-digested B95-8 viral DNA and by comparison of the EcoRI, HindIII, and Sall cleavage patterns with those predicted from published cleavage maps $(4,21)$. Table 1 gives the properties of the plasmids used in the experiments described here, and Fig. 1 shows ethidium bromide-stained profiles of the cleaved plasmid DNAs.

Purification of viral and plasmid DNAs. B95-8 viral DNA was extracted from virions purified by banding in dextran T10 gradients as previously described (10). The HR-1 DNA which was used to form in vitrolabeled probes was extracted from crude virus pellets. These pellets were obtained by centrifugation of clarified HR-1 culture supernatant for $90 \mathrm{~min}$ at $9,000 \mathrm{rpm}$ in a Sorvall GS3 rotor. The DNA preparations obtained in this way contained cellular DNA in addition to $\mathrm{EBV}$ sequences.
Recombinant plasmid DNAs were prepared as follows. Bacterial cultures (1 liter) were grown at $37^{\circ} \mathrm{C}$ in TY broth (1\% tryptone, $0.5 \%$ yeast extract, $0.5 \%$ $\mathrm{NaCl}$, and $0.1 \%$ glucose, $\mathrm{pH} 7.2$ ) to an optical density at $600 \mathrm{~nm}$ of 0.6 , at which time chloramphenicol was added at $50 \mu \mathrm{g} / \mathrm{ml}$ to obtain plasmid amplification, and the incubation was continued overnight. Extraction of the plasmid DNA followed the methods of Clewell and Helinski (3), and the DNA was purified by banding to equilibrium in cesium chloride-ethidium bromide density gradients.

End labeling of DNA. The cloned BamHI-H fragment was cleaved at the BglII site, treated with bacterial alkaline phosphatase (Bethesda Research Laboratories), and end labeled as described by Smith and Birnstiel (23), using polynucleotide kinase (Be-

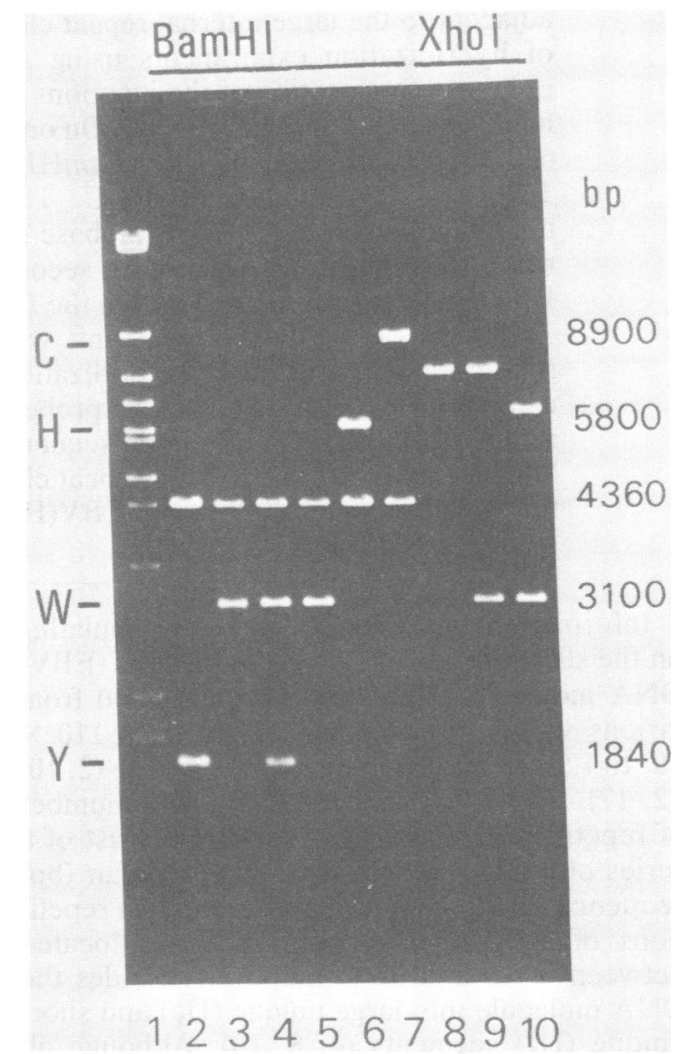

FIG. 1. Characterization of the molecularly cloned BamHI fragments from EBV (B95-8) DNA used in this study. Plasmid DNAs were cleaved with restriction enzymes, electrophoresed through a $1 \%$ agarose gel for $750 \mathrm{~V} \times \mathrm{h}$, and stained with ethidium bromide. The size markers (slot 1) consist of a mixture of the EcoRI and HindIII cleavage products from phage lambda DNA. The samples in slots 2 through 7 were each cleaved with BamHI. Slot 2, pSL3 (BamHI-Y); slot 3, pSL9 (BamHI-W); slot 4, pSL8 (BamHI-YW); slot 5, pSL76 (BamHI-WW); slot 6, pSL77 (BamHI-H); slot 7, pSL93 (BamHI-C). Samples in slots 8 through 10 were each cleaved with XhoI. Slot 8, pSL9 (BamHIW); slot 9, pSL76 (BamHI-WW); slot 10, pSL8 (BamHI-YW). 
thesda Research Laboratories) and $\left[\gamma-{ }^{32} \mathrm{P}\right] \mathrm{ATP}$ (New England Nuclear Corp.).

Restriction enzyme digestion and gel electrophoresis. Restriction enzymes were purchased from either Bethesda Research Laboratories or New England Biolabs. Cleaved plasmid DNAs (100 to $500 \mathrm{ng}$ ) were analyzed by electrophoresis in Tris-phosphate buffer through agarose gels (11) in the form of either vertical slabs or horizontal submarine gels. The DNA was visualized by staining with ethidium bromide $(1 \mu \mathrm{g} /$ ml). Partial digests of BamHI-H DNA were obtained as follows. The reaction mix $(50 \mu \mathrm{l})$ contained $5 \mu \mathrm{g}$ of sonicated calf thymus DNA, $1 \mu \mathrm{g}$ of ${ }^{32} \mathrm{P}$-labeled BamHI-H DNA, and $0.5 \mathrm{U}$ of the selected restriction enzyme. After 5, 10, 15, 30, and $90 \mathrm{~min}$ of incubation at $37^{\circ} \mathrm{C}, 10-\mu l$ portions of reaction mix were removed into stop buffer (10 mM Tris, pH 7.8, $20 \mathrm{mM}$ EDTA, $10 \%$ glycerol, and $0.01 \%$ bromophenol blue). Half of each sample was analyzed by electrophoresis through a 1\% agarose gel, and those samples giving an appropriate range of partial digestion products were subsequently pooled and analyzed on a master gel. The 3.1kb Bam HI repeat fragment was isolated from a BamHI digest of pSL9 $(10 \mu \mathrm{g})$ which had been electrophoresed through a $20-\mathrm{cm}$ cylindrical gel of $0.8 \%$ agarose. The gel was stained briefly with ethidium bromide, and the DNA was visualized under long-wave UV illumination. The appropriate band was excised, extracted in 5 $M$ sodium perchlorate at $60^{\circ} \mathrm{C}$, and absorbed onto hydroxylapatite (13). The DNA was eluted with $0.4 \mathrm{M}$ potassium phosphate buffer and concentrated by ethanol precipitation.

In vitro labeling and hybridization. The probes used consisted of portions $(0.5$ to $1.0 \mu \mathrm{g})$ of $\mathrm{HR}-1$ or B95-8 viral DNA, recombinant plasmid DNA, or isolated EBV DNA fragments which were labeled in vitro with $\left[{ }^{32} \mathrm{P}\right] \mathrm{TTP}$ and $\left[{ }^{32} \mathrm{P}\right] \mathrm{dCTP}$ (New England Nuclear) by nick translation (19).

Electrophoretically separated DNA fragments were transferred from the agarose gels to nitrocellulose filters as described by Southern (24). The filters were sealed in plastic bags and preincubated at $63^{\circ} \mathrm{C}$ in hybridization buffer $(0.8 \mathrm{M} \mathrm{NaCl}, 0.05 \mathrm{M}$ Tris, $\mathrm{pH} 7.4$, $0.001 \mathrm{M}$ EDTA, $0.2 \%$ sodium dodecyl sulfate, $20 \%$ formamide, and $1 \times$ Denhardt solution [0.02\% Ficoll, $0.02 \%$ polyvinyl pyrrolidone, and $0.02 \%$ bovine serum albumin]) plus $50 \mu \mathrm{g}$ of sheared, denatured calf thymus DNA per ml. Hybridization was carried out at $63^{\circ} \mathrm{C}$ for 24 to $48 \mathrm{~h}$ with $1 \times 10^{6}$ to $5 \times 10^{6} \mathrm{cpm}$ of denatured probe in $8 \mathrm{ml}$ of hybridization buffer. After annealing, filters were washed successively with $2 \times$ SSC (SSC = $0.15 \mathrm{M} \mathrm{NaCl}$ plus 0.015 sodium citrate), fresh hybridization buffer at $63^{\circ} \mathrm{C}, 2 \times \mathrm{SSC}$, and finally $0.01 \times \mathrm{SSC}$. Autoradiography was carried out for 1 to 14 days at $-70^{\circ} \mathrm{C}$ with enhancing screens.

\section{RESULTS}

Relative organization of cloned BamHi-H, -Y -W, and -C fragments in the viral genome. In our previous studies on the internal repeat cluster and its flanking sequences in EBV(B95-8) DNA using cleaved viral DNA and isolated fragment probes, we suggested that the outside physical termini of the repeat units lay closer to the BglII site than to the BamHI site on the $\mathrm{U}_{\mathrm{S}}$ side of the cluster and closer to the BamHI site than the $B g l I I$ site on the $\mathrm{U}_{\mathrm{L}}$ side (10). This interpretation was based on the assumption that the cluster contained an exactly integral number of copies of the tandemly duplicated $3.1-\mathrm{kb}$ sequence. However, subsequent studies indicated that the structure was more complicated. In particular, double cleavages with PvuII plus BamHI or $B g I I$ revealed that $B a m H I$ mapped closer to the termini than did $B g I I I$ at both ends of the cluster and that BamHI released an extra complete copy of the repeat unit (i.e., $13 \times 3.1 \mathrm{~kb}$ ) relative to $B g l I I(12 \times 3.1 \mathrm{~kb})$. To examine this phenomenon further, we constructed pBR322 plasmids containing the cloned $3.1-\mathrm{kb}$ repeats and flanking sequences from $\operatorname{EBV}(\mathrm{B} 95-8)$ virion DNA. The plasmids selected for use in the mapping work described here contained either single BamHI fragment inserts or combinations of adjacent BamHI fragments from a partial digest (Fig. 1). Table 1 summarizes their characteristic sizes, orientation, and map coordinates.

Figure 2 is a composite diagram illustrating the arrangement of the appropriate BamHI fragments relative to the internal repeat cluster and its flanking regions on both the $U_{L}$ and $U_{S}$ sides in the parent viral DNA molecule. The observation that the pSL8 plasmid, which contains a single copy each of both the BamHI-Y and BamHI-W fragments, released a complete 3.1kb "repeat unit" after cleavage with XhoI (Fig. 1, slot 10) confirmed our earlier evidence that these two fragments map adjacent to one another at the $U_{L} /$ repeat junction in the parent viral genome $(4,8,10)$. In addition, this "partial" BamHI-YW clone provided key information for establishing the correct orientations of both the BamHI-Y and BamHI-W fragments relative to the left $\left(U_{L}\right)$ and right $\left(U_{S}\right)$ ends of the intact EBV DNA molecule. We previously identified the flanking fragment on the $\mathrm{U}_{\mathrm{L}}$ side as BamHI$C$ (10), and the orientation of this fragment was deduced from the positions of the internal EcoRI sites (8). Skare and Strominger (22) and Dambaugh et al. (4) reported that BamHI-H is the next fragment adjacent to BamHI-Y on the $U_{S}$ side of the repeats. The orientation of BamHI-H shown in Fig. 2 is the only arrangement which can accommodate the 10.3-kb BgllI-C species known to be the $U_{S}$ flanking fragment in a BglII digest (10). These deductions indicate that the orientation originally assigned to the BglII-Rrepeat unit in Fig. 11d of Hayward et al. (10) needs to be reversed.

Location of the $U_{L}$ and $U_{S}$ repeat junctions by restriction site mapping. Figure 3 summarizes the physical maps of plasmids containing Bam HI-H, -Y, -W, - YW, and -C fragments of EBV(B95-8) DNA. These were constructed by performing single, double, and triple restriction 
(a)

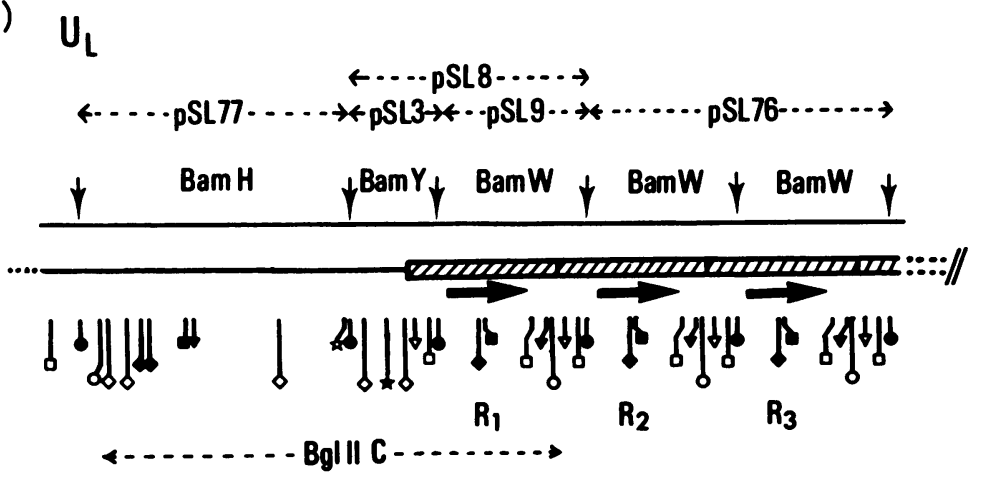

(b)

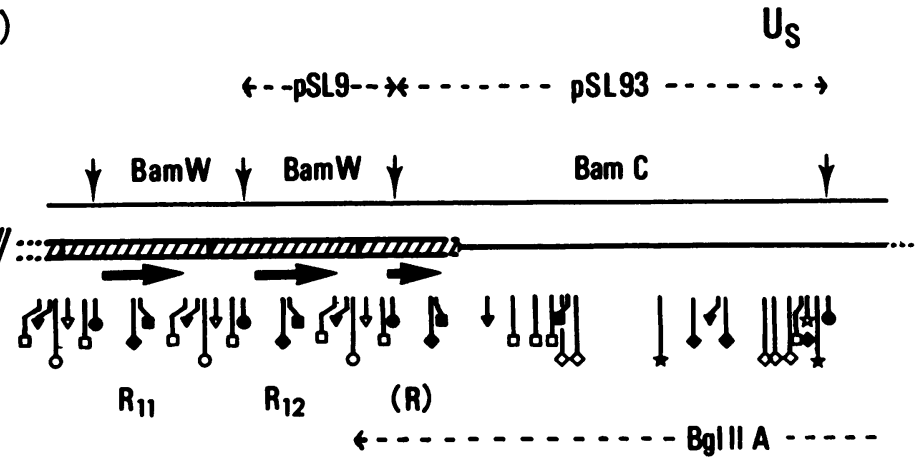

FIG. 2. Arrangement and orientation of BamHI-H, -Y, -W (repeat), and $-\mathrm{C}$ in B95-8 virion DNA and localization of the junctions between the unique sequences and 3.1-kb internal repeat cluster by restriction site analysis. (a) $U_{L}$ side between map coordinates 0.650 to 0.750 ; (b) $U_{S}$ side between coordinates 0.870 to 0.970 . Hatched bars and horizontal arrows indicate the positions of individual $3.1-\mathrm{kb}$ repeats at the edges of the internal repeat cluster. Symbols are used to illustrate the pattern of mapped restriction sites within the cloned fragments. Only those cleavages which are most relevant for determining the repeat/unique junctions are included. ( $(\bullet)$

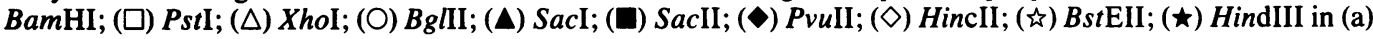
and $E c o R I$ in (b).

enzyme digests and measuring the size of the DNA fragments generated by using known molecular weight markers. To ensure as great a degree of accuracy as possible, many different enzyme combinations were used to determine the location of each restriction site. The doublecut mapping technique provided adequate information for the subsequent hybridization studies. However, because it is difficult to map regions in which the sites for a given enzyme occur less than 200 to $300 \mathrm{bp}$ apart by this procedure, the map locations of the smallest fragments, particularly those in BamHI-C, should be considered tentative. In the case of BamHI-H, some cleavage sites were also mapped by using the technique of partial digestion of end-labeled DNA described by Smith and Birnsteil (23). We had previously described the relative position of $\mathbf{1 0}$ cleavage sites within the 3.1-kb BamHI repeat (10), and these data were confirmed by using a cloned monomer BamHI-W-repeat unit and a cloned dimer of the repeat.
Inspection of the cleavage sites within BamHI-Y (Fig. 2a) revealed that the first three sites (BamHI, PstI, and XhoI) of the eight-site repeat pattern were present, but the fourth site, BglII, was missing. This suggested that the repeat sequences extended into BamHI-Y to a position no further than $200 \mathrm{bp}$ beyond the $\mathrm{XhoI}$ site. A similar examination of the $U_{\mathrm{S}}$ /repeat junction at the opposite end of the cluster (Fig. 2b) showed that, of the eight cleavage sites present in the repeat unit, only two (PvuII and SacII) were present in BamHI-C; the third would be the PstI site. Therefore, the repeat sequences within the flanking Bam HI-C fragment extended no further than $1,000 \mathrm{bp}$ beyond the SacII site.

Location of $U_{L}$ and $U_{S}$ repeat junctions by blot hybridization. Proof that these matching cleavage patterns do represent homologous sequences came from Southern blot hybridization experiments in which a repeat DNA probe was hybridized to a variety of restriction enzyme 
PSL3

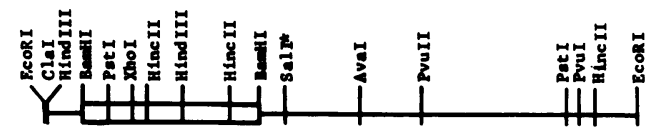

PSL8
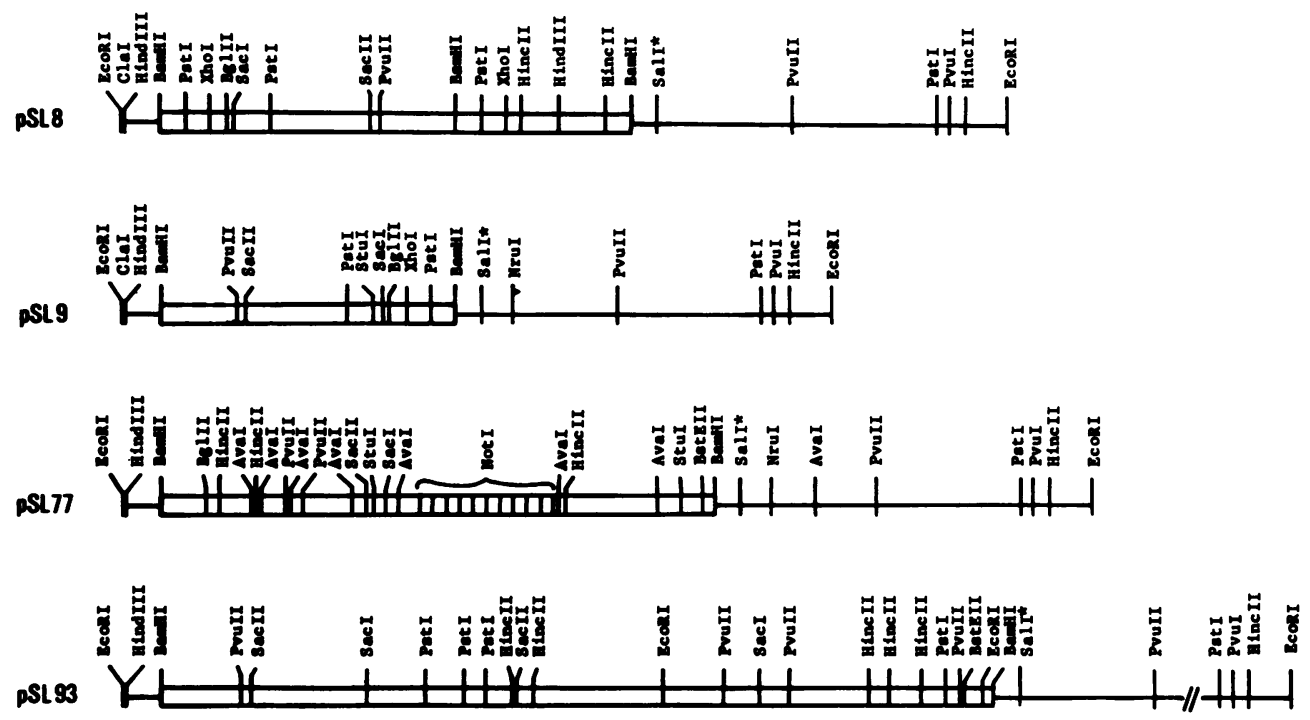

kb

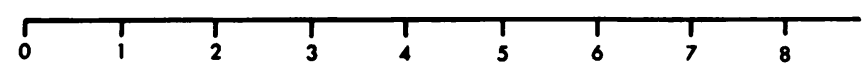

FIG. 3. Restriction site maps for pSL3 (BamHI-Y), pSL8 (BamHI-YW), pSL9 (BamHI-W), pSL77 (BamHIH), and pSL93 (BamHI-C). The regions drawn as double lines represent EBV DNA sequences; the plasmid pBR322 sequences are represented by a single line. The asterisk indicates that the SalI site is also a HincII site. The size scale for insert DNA is given in kilobases. The following restriction enzymes do not cleave these fragments. BamHI-Y, no sites for AvaI, BglII, BstEII, EcoRI, HpaI, KpnI, PvuI, PvuII, SacI, SacII, SalI, and XbaI; BamHI-repeat, no sites for BstEII, ClaI, EcoRI, HincII, HindIII, HpaI, KpnI, NotI, NruI, PvuI, SalI, and XbaI; BamHI-H, no sites for ClaI, HindIII, KpnI, NruI, PstI, PvuI, SalI, XbaI, and XhoI; BamHI-C, no sites for BglII, HindIII, HpaI, KpnI, PvuI, SalI, XbaI, and XhoI.

digests of the BamHI-Y and BamHI-C fragments. This approach also addressed the possibility that homologous but diverged sequences, lacking the characteristic repeat-unit cleavage sites, may have extended beyond the boundaries suggested above. An example of the results obtained by hybridizing restriction digests of the BamHI-Y fragment with a BamHI-repeat probe is shown in the upper panel of Fig. 4. Our interpretations of the results of this and similar blot hybridization experiments (not shown) are summarized in tabular form in the lower panel of Fig. 4. The use of a large set of different restriction fragments has the advantage of minimizing potential misinterpretations which could arise from occasional hybridization artifacts in individual tracks or from aberrant hybridization properties associated with localized unusual DNA structure (see later). Relevant observations include the following: (i) the cloned BamHI-Y fragment hybridized with the BamHIW-repeat probe as expected; (ii) the hybridiza- tion within BamHI-Y occurred within sequences which map directly adjacent to BamHI-W in virion DNA; (iii) the ratio of hybridization to BamHI-Y relative to BamHI-W in the pSL8 plasmid was consistent with flanking sequence homology totaling in the order of 400 to 1,000 bp; (iv) the region giving hybridization appeared to be confined to a contiguous stretch of sequences containing sites for BamHI, HinfI, PstI, and $\mathrm{XhoI}$; and (v) a boundary between homologous and nonhomologous sequences could be detected between the XhoI and HincII sites located 520 and 680 bp from the BamHI site. We conclude that a contiguous 600 -bp segment of the flanking BamHI-Y fragment ( $U_{L}$ side) consists of repeat-unit sequences and that no additional diverged "repeat-like" sequences exist beyond the characteristic cleavage sites identified in the previous section.

Figure 5 presents similar analyses with restriction digests of the BamHI-C fragment to examine the extent of homology between the BamHI- 

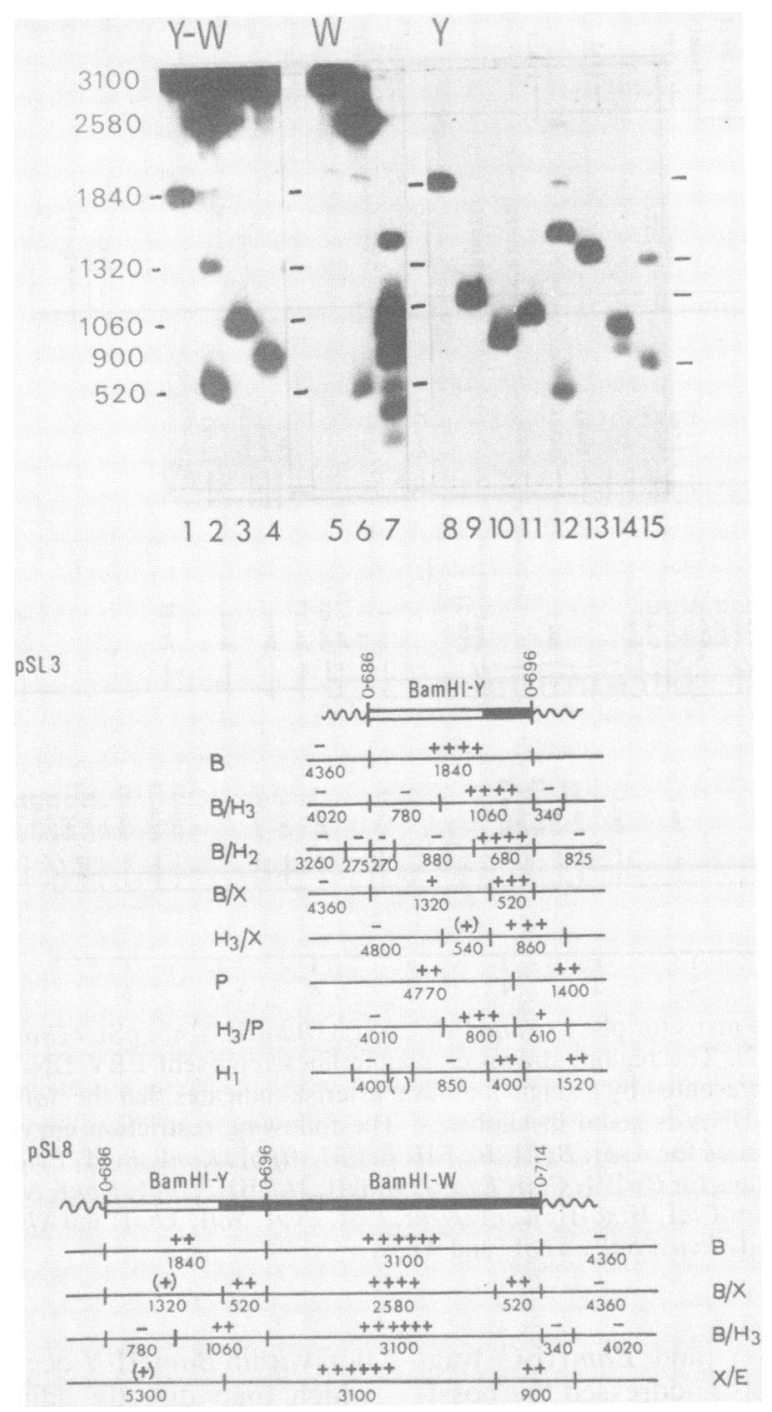

FIG. 4. Localization of the $U_{V} / 3.1-k b$ repeat junction by hybridization analysis. The autoradiograph shows the hybridization of an in vitro-labeled Bam HI-repeat fragment probe to restriction enzyme digests of pSL8 (BamHI-YW), pSL9 (BamHI-W), and pSL3 (BamHI-Y) DNAs which had been electrophoresed through a $1.4 \%$ agarose gel for $800 \mathrm{~V} \times \mathrm{h}$. Only that region of the gel containing fragments of less than $3,100 \mathrm{bp}$ is presented. The numbers indicate fragment sizes in base pairs. Individual tracks contain: pSL8 DNA digested with (1) Bam HI, (2) BamHI/XhoI, (3) BamHI/HindIII, and (4) EcoRI/XhoI; or pSL9 DNA digested with (5) BamHI, (6) BamHI/XhoI, and (7) Hinfl; or pSL3 DNA digested with (8) BamHI, (9) BamHI/HindIII, (10) BamHI/HincII, (11) HindIII/ XhoI, (12) Hinfl, (13) PstI, (14) PstI/HindIII, and (15) BamHI/XhoI. A summary and interpretation of the results from this and other similar hybridization experiments are also presented. Solid bars depict those portions of the cloned inserts that contain sequences homologous to the repeat unit probe, and open bars represent regions lacking repeat sequence homology. Wavy lines denote pBR322 sequences. Individual fragments are identified by their measured sizes in base pairs, and those which hybridize to the BamHI-W-repeat probe are assigned (+), $(++)$, or $(+++)$, etc., notations, depending on hybridization intensity. Lack of hybridization is indicated by $(-)$. The abbreviations for the restriction enzymes used to cleave the DNA are as follows: B, BamHI; E, EcoRI; H1, HinfI; H2, HincII; H3, HindIII; P, PstI; X, XhoI.

repeat probe and the flanking DNA on the $\mathrm{U}_{\mathrm{S}}$ side of the 3.1-kb cluster. The results of these experiments provided evidence that: (i) again, all of the hybridization was restricted to the region directly adjacent to the repeat cluster; (ii) in this case, the homology ended in a poorly defined segment between the SacII site 915 bp beyond BamHI and the SacI site 2,100 bp away 


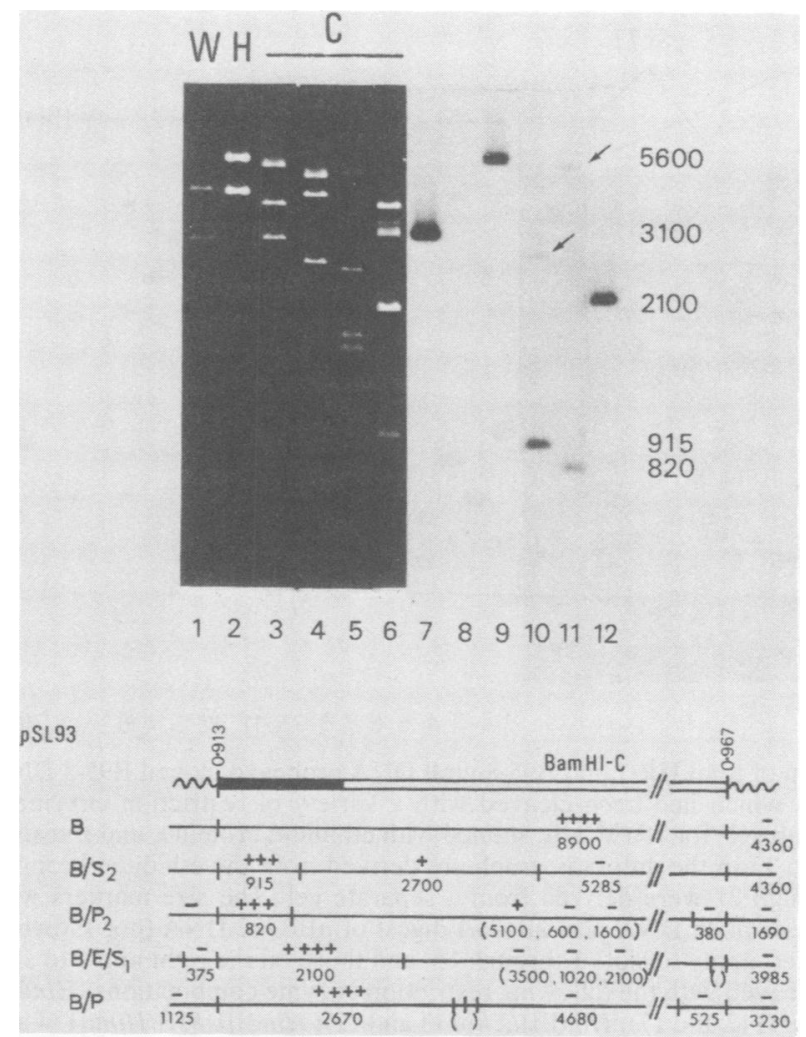

FIG. 5. Localization of the $U_{\mathrm{S}} / 3.1-\mathrm{kb}$ repeat junction by hybridization analysis. The autoradiograph illustrates hybridization of an in vitro-labeled, isolated BamHI-repeat fragment probe to a blot of the cleaved pSL9 (BamHI-W), pSL77 (BamHI-H), and pSL93 (BamHI-C) DNAs shown in the adjacent ethidium bromide stain. The DNA samples were electrophoresed through a $1.4 \%$ agarose gel for $700 \mathrm{~V} \times \mathrm{h}$. Strongly positive fragments are identified by their sizes in base pairs, and weakly hybridizing fragments are indicated by arrows. Individual tracks contained the following digests: (1 and 7) pSL9, BamHI; (2 and 8) pSL77, BamHI; (3 and 9) pSL93, BamHI/EcoRI; (4 and 10) pSL93 BamHI/SacII; (5 and 11) pSL93, BamHI/PvuII; (6 and 12) pSL93 BamHI/EcoRI/SacI. The figure includes a diagrammatic summary of the results from this and other additional hybridization experiments. The format and symbols used are the same as in Fig. 4. Restriction enzyme sites are abbreviated as follows: B, BamHI; E, EcoRI; P, PstI; P2, PvuII; S1, SacI; S2, SacII.

from BamHI; and (iii) based on the relative hybridization intensity to nearby fragments, no more than 250 to 500 bp in the DNA beyond the SacII site formed hybrids. Therefore, a presumably contiguous segment of approximately 1,300 bp of the flanking fragment BamHI-C ( $\mathrm{U}_{\mathrm{S}}$ side) has homology with the repeat unit probe.

In conclusion, the results of the detailed cleavage site mapping together with the hybridization experiments clearly confirm that the sequences forming the physical termini of the repeat cluster on the $U_{L}$ side come from a different position within the 3.1-kb repeat unit than do those on the $U_{S}$ side; i.e., there is a nonintegral number of copies of the repeat unit in the cluster.

Localization of the HR-1 deletion. Previous work has indicated that the deletion in HR-1 encompasses the HindIII site between the
HindIII-A and -B on the $\mathrm{U}_{\mathrm{L}}$ side of the repeat cluster $(2,11,17)$, i.e., presumably the single HindIII site within BamHI-Y. To further define the limits of the deletion within the $U_{L}$ sequences, Southern transfers containing restriction enzyme digests of the cloned BamHI-Y and BamHI-H fragments from EBV(B95-8) were hybridized with in vitro-labeled probes of total B95-8 and HR-1 DNAs (Fig. 6). The location of the deletion in HR-1 was defined by those restriction fragments which hybridized with a B958 probe but not with an HR-1 probe.

Figure 7 presents a summary and interpretation of all of the results of hybridization experiments to define the HR-1 deletion. Our analysis for BamHI-Y indicated the following: (i) HR-1 lacked sequences located within the BamHI-Y fragment of B95-8; (ii) the deletion included an apparently contiguous region of $1,300 \mathrm{bp}$ which 


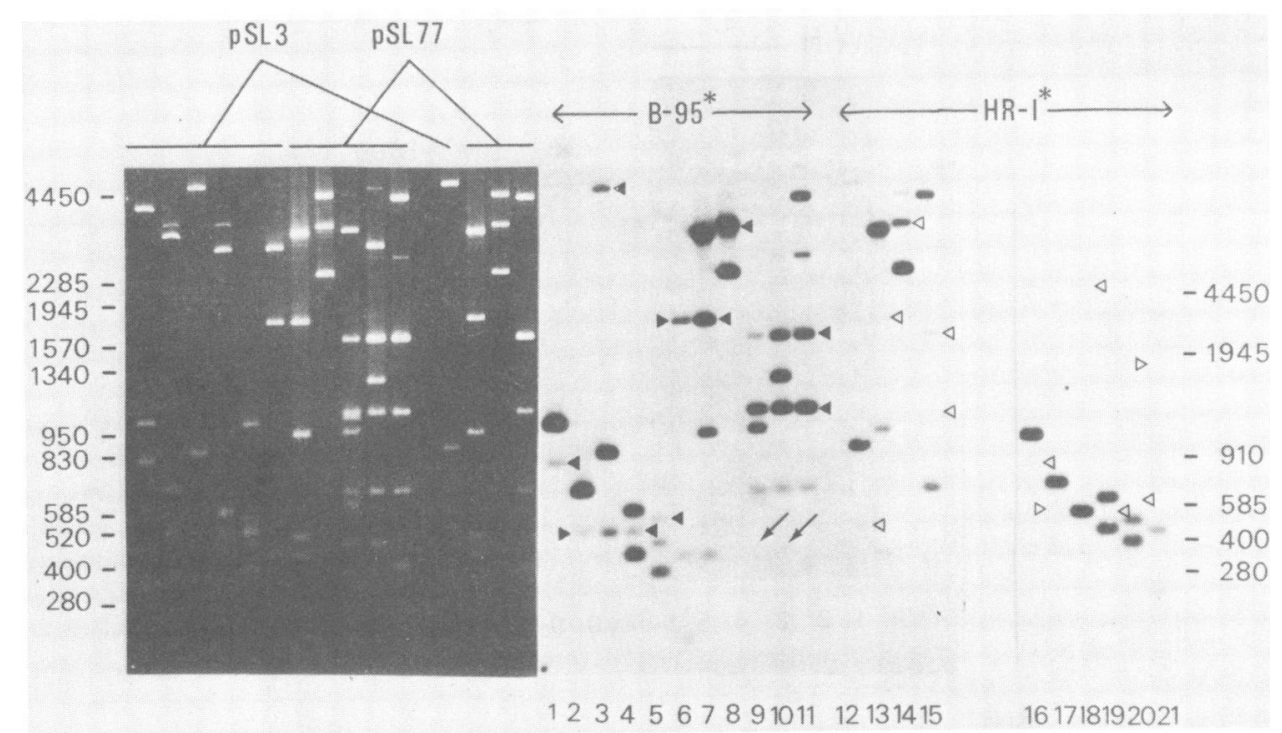

FIG. 6. Hybridization of total HR-1 and B95-8 viral DNA probes to cloned B95-8 DNA fragments. BamHI-Y and BamHI-H plasmids which had been cleaved with a variety of restriction enzymes were electrophoresed through $1.5 \%$ agarose slab gels for $750 \mathrm{~V} \times \mathrm{h}$, stained with ethidium bromide, and transferred onto nitrocellulose sheets. Tracks 1 through 15 in the autoradiograph are derived from the ethidium bromide-stained gel shown to the left. Tracks 16 through 21 were derived from a separate gel. The size markers were HindIII and EcoRI/ HindIII digests of phage lambda DNA plus an AluI digest of pBR322 DNA (not shown). Note that the sizes in base pairs given on the left apply to slots 1 through 15 , and those on the right apply to slots 16 through 21 . pSL3 (BamHI-Y) DNA was cleaved with the following restriction enzyme combinations: HindIII/BamHI (tracks 1 and 16); HindIII/BamHI/HincII (2 and 17);HindIII/XhoI (3 and 12);HindIII/PstI/HincII (4 and 19); HindIII/Hinf I (5 and 20); HindIII/AvaI (6 and 21); and HindIII/BamHI/XhoI (18). pSL77 (BamHI-H) was digested with: HindIII/ HincII (slots 7 and 13); BamHI/SacI (8 and 14); BamHI/AvaI (9); HindIII/AvaI (10); and SacI/AvaI (11 and 15). Tracks 1 through 11 were hybridized with in vitro-labeled B95-8 viral DNA, and tracks 12 through 21 were hybridized with an in vitro-labeled HR-1 viral DNA probe. The triangles indicate bands which form hybrids with the B95-8 probe (solid) but are either negative or hybridize with reduced intensity when the probe is HR-1 DNA (open). The arrows indicate the position of a 480-bp Aval viral DNA fragment which does not hybridize to the B95-8 probe (see text). Note that with B95-8 DNA probes, those portions of BamHI-Y that contain sequences from the 3.1-kb repeat unit hybridize more strongly than do the unique-sequence portions because each $B 95-8$ DNA molecule contains 12 copies of the $3.1-\mathrm{kb}$ repeat. This phenomonen is less obvious with the HR-1 DNA probe because of the lower copy number for the repeats in HR-1.

in B95-8 contained sites for the BamHI, HindIII, HincII, and Hinfl enzymes; and (iii) those sequences within BamHI-Y which did form hybrids with the HR-1 probe began between the $X h o I$ and HincII sites at the repeat/unique junction identified in the previous section. Therefore, the HR-1 deletion removed all uniquesequence DNA from the BamHI-Y fragment. Note that because HR-1 is known to retain several copies of the 3.1-kb BamHI repeats, these data do not necessarily define the actual boundary of the deletion.

A similar analysis was performed on the adjacent BamHI-H fragment. Hybridization with an in vitro-labeled HR-1 DNA probe indicated that the homology extended beyond the SacI site (Fig. 6, slots 8 and 14) because fragments mapping immediately to the right of the SacI site were positive, although hybridizing with reduced intensity. Use of the HincII enzyme (Fig.
6 , slots 7 and 13) localized the deletion boundary to within the region between the $S a c I$ site 4,300 bp from the BamHI-H to -Y junction and the HincII site 2,450 bp away from it. In the hope of mapping the $U_{L}$ side of the deletion more precisely, we searched for enzymes which cleaved within this large undefined segment of BamHI$H$. Although numerous enzymes were screened (including those with 4- and 5-bp recognition sites such as AluI, HinfI, MboII, and TaqI), only two, AvaI and NotI, cleaved within the 1,830-bp SacI/HincII fragment. AvaI removed approximately 200 bp, but digestion with NotI revealed that the sequence complexity within this region was much less than anticipated (see below). This accounted for the paucity of restriction enzyme cleavage sites.

Detection of new small tandem repeats in BamHI-H. Cleavage of the pSL77 plasmid containing BamHI-H with NotI yielded two bands, 
(a) PSL77

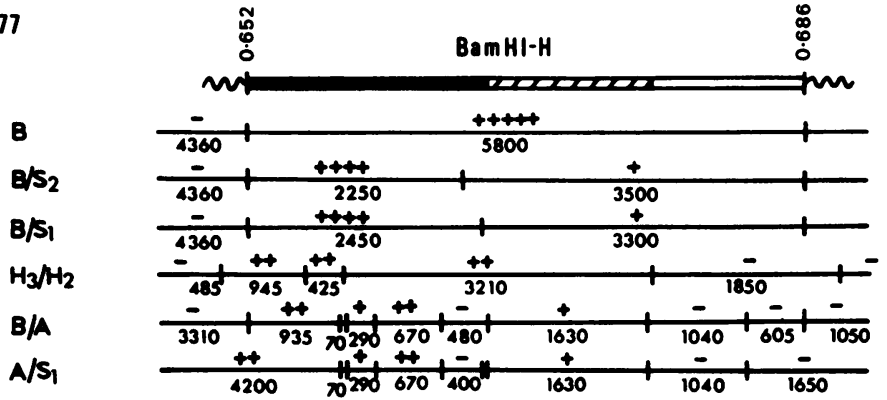

(b) $p S L 3$

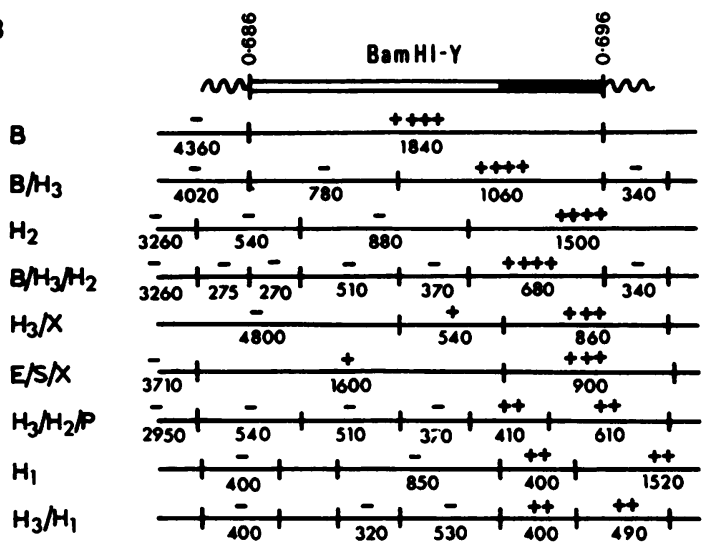

FIG. 7. Summary and interpretation of the hybridization results which define the extent of the HR-1 deletion. Some of the data originate from the experiments shown in Fig. 6. The solid bars represent DNA sequences within the cloned B95-8 BamHI-H and -Y fragments that are retained in the HR-1 genome. Open bars indicate deleted sequences, and the hatched bar denotes the region of uncertainty in BamHI-H. Wavy lines indicate pBR322 sequences. Fragment sizes are given in base pairs, and hybridization (or lack of hybridization) with an HR-1 probe is indicated by $(+)$ and $(-)$, respectively. The aberrant hybridization of the 480 -bp Aval fragment from pSL77 is discussed in the text. The restriction enzymes used to cleave the DNA are given at the left of the diagram: A (AvaI); B (BamHI); E (EcoRI); H1 (HinfI); H2 (HincII); H3 (HindIII); P (PstI); S (SalI); S1 (SacI); S2 (SacII); and X (XhoI).

one very large and the other containing DNA measuring only 135 bp in size (Fig. 8, slot 2). Additional cleavage with SacI and SacII showed that a NotI site was located 385 and 580 bp from the SacI and SacII sites, respectively (Fig. 8, slots 3 through 6). However, in these digests the intense staining of the 135 -bp band relative to the two flanking fragments indicated that it must contain multiple copies of the 135-bp fragment. To determine the exact number of copies of this fragment and to further define the locations of the NotI sites, pSL77 DNA which had been end labeled with [ $\left.{ }^{32} \mathrm{P}\right]$ phosphate at the BgIII site was first cleaved to completion with HindIII and then subjected to partial digestion with NotI, SacI, or HincII. As shown in Fig. 8 (slots 12 and 16), the NotI partial digest resulted in a ladder of 11 bands with sizes increasing in increments of 135 bp. Thus, the HR-1 deletion terminated within an 1,830-bp SacI/HincII fragment which, in B95-8, contained 11 adjacent copies of a 135bp repetition. (The presence of multiple copies of the 135-bp NotI fragment within BamHI-H is unlikely to have arisen as an artifact of cloning, since the BamHI-H fragment derived from pSL77 was identical in size to that isolated from B95-8 virion DNA.)

In an attempt to determine whether the HR-1 deletion includes part or all of the small repeat cluster, HR-1 and B95-8 DNA probes were hybridized to blots of NotI-cleaved BamHI-H DNA. Unfortunately, both the HR-1 and B95-8 DNA probes failed to anneal to the 135-bp NotI fragment (Fig. 8, slot 7). However, the HR-1 probe did hybridize to both the 580-bp SacII/ NotI fragment and the 385-bp SacI/NotI fragment (not shown), indicating that sequences within these fragments were apparently retained in HR-1. The possible low-efficiency transfer to the nitrocellulose of such small-sized fragments could not alone account for the lack of hybridization to the 135-bp NotI repeats because in parallel experiments, similarly sized pBR322 fragments gave positive results with a pBR322 


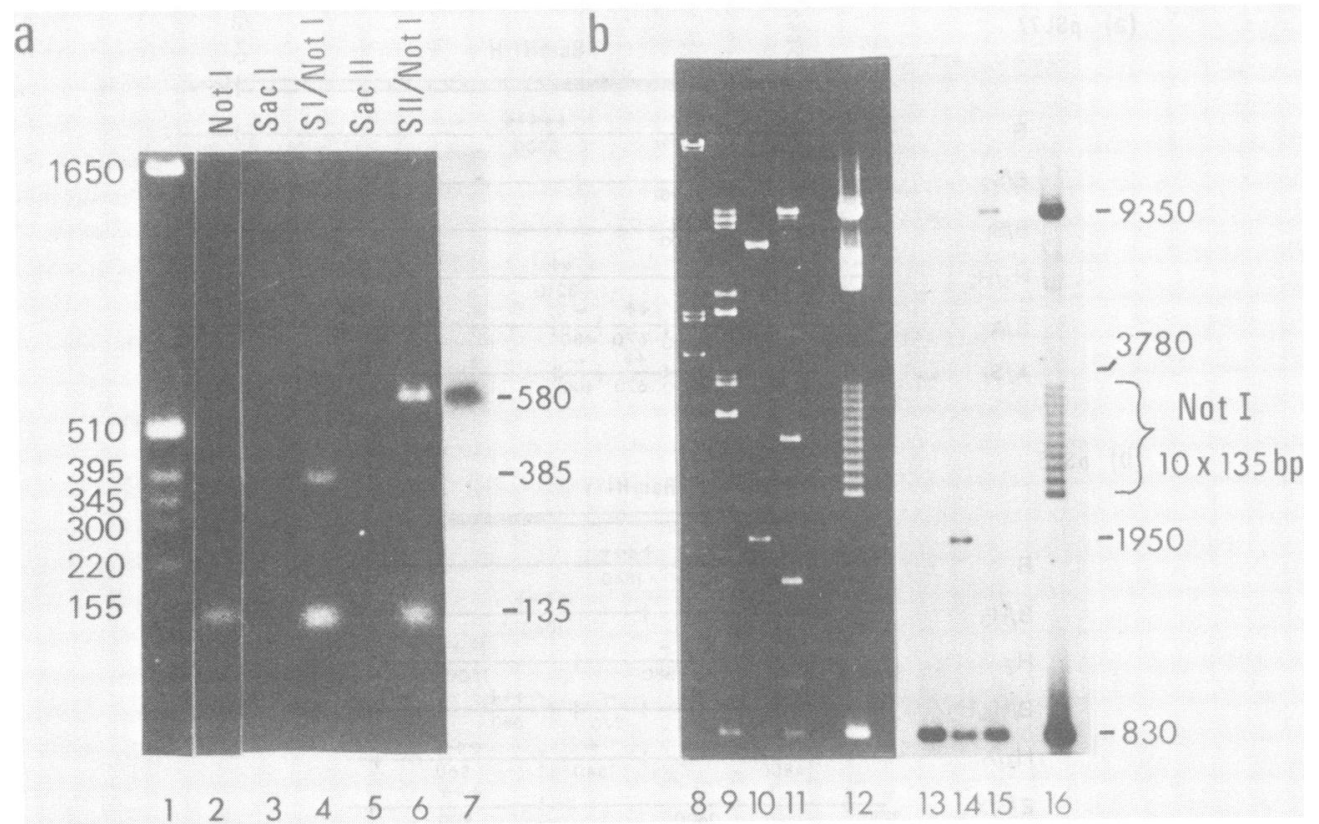

FIG. 8. Cleavage of the BamHI-H fragment using the NotI restriction enzyme and demonstration of the Not I repeat "ladder." (a) Ethidium bromide stain of pSL77 (BamHI-H) DNA cleaved with NotI (slot 2), SacI (slot 3), SacI/NotI (slot 4), SacII (slot 5), and SacII/NotI (slot 6). The autoradiograph (slot 7) shows hybridization of a total B95-8 DNA probe to a SacIL/NotI digest of pSL77. The size references (slot 1) are Hinf I fragments of pBR322 DNA. The DNA samples were electrophoresed through a $1.6 \%$ agarose gel for $600 \mathrm{~V} \times \mathrm{h}$. Only the lower-molecular-weight region of the gel is shown. (b) Ethidium bromide stain and autoradiograph of pSL77 DNA which had been end labeled with ${ }^{32} \mathrm{P}$ at the BglII site, cleaved with HindIII, and subjected to partial digestion with HincII (slots 9 and 13), SacI (slots 10 and 14), AvaI (slots 11 and 15), or NotI (slots 12 and 16). The DNA samples were electrophoresed through a $1 \%$ agarose gel for $1,000 \mathrm{~V} \times \mathrm{h}$. The constant band at $830 \mathrm{bp}$ represents the HindIII/BglII fragment. Size markers were provided by an EcoRI/HindIII double digest of phage lambda DNA (slot 8).

DNA probe. Apparently, the 135-bp fragment itself has some unusual structure or base composition which interferes with either the blotting or the hybridization reaction. A further example of anomolous hybridization behavior could be seen in AvaI digests of BamHI-H (Fig. 7, slots 9 and 10). Unexpectedly, the 480-bp AvaI fragment located 3,280 to 3,760 bp from the BamHI-H to -Y junction did not self-hybridize with a B95-8 probe even though fragments which mapped on either side of it were positive (Fig. 6). This lack of hybridization was also observed with an HR-1 probe (not shown). Presumably, the 480-bp AvaI fragment also contains unusual structural features which inhibit either blotting or hybridization with the probe DNAs.

Since the HR-1 sequences extend up to the SacI site on one side of the repeat cluster and are absent $145 \mathrm{bp}$ beyond the cluster on the other side (i.e., after the HincII site), it seems probable that the deletion terminates somewhere within the small repeat units themselves. Thus, the HR-1 deletion removes single-copy DNA which is bounded on either side by tandemly reiterated sequences: on the one side by the previously described 3.1-kb BamHI repeat cluster and on the other by a newly identified set of 135-bp NotI repeats. Figure 9 presents our current understanding of the location of the HR1 deletion and the structure of the flanking DNA. Further definition of the physical boundaries of the deletion with each set of tandem repeats will require direct analysis of cloned DNA fragments from HR-1 virus.

\section{DISCUSSION}

We have constructed relatively detailed restriction enzyme maps for the region of the EBV genome adjacent to the 3.1-kb repeat unit cluster. The BamHI-Y and -C fragments which flank the 3.1-kb internal repeats were shown to contain approximately 600 and $1,300 \mathrm{bp}$, respectively, of repeat-sequence DNA. The two flanking $B a m H I$ fragments thus contain only $60 \%$ of a complete repeat sequence. When EBV(B95-8) DNA is subjected to cleavage with the BglII restriction endonuclease, the two flanking fragments are $B g I I I-C$ and $B g l I I-A(10)$, and these two fragments together contain $5,050 \mathrm{bp}$ of re- 
(a)

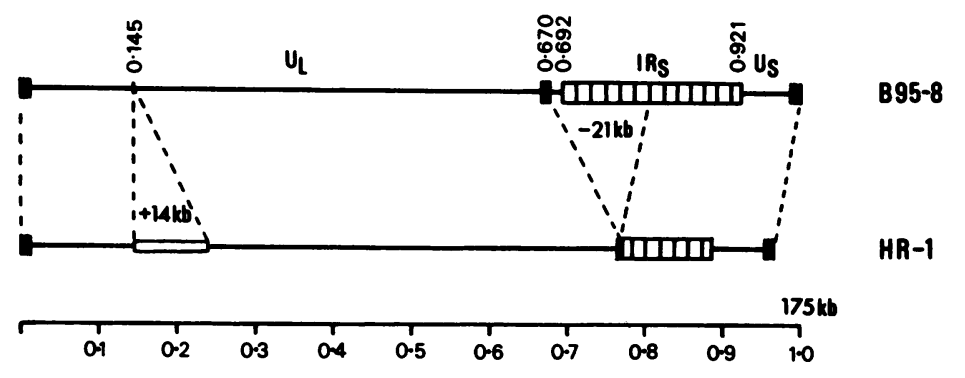

(b)

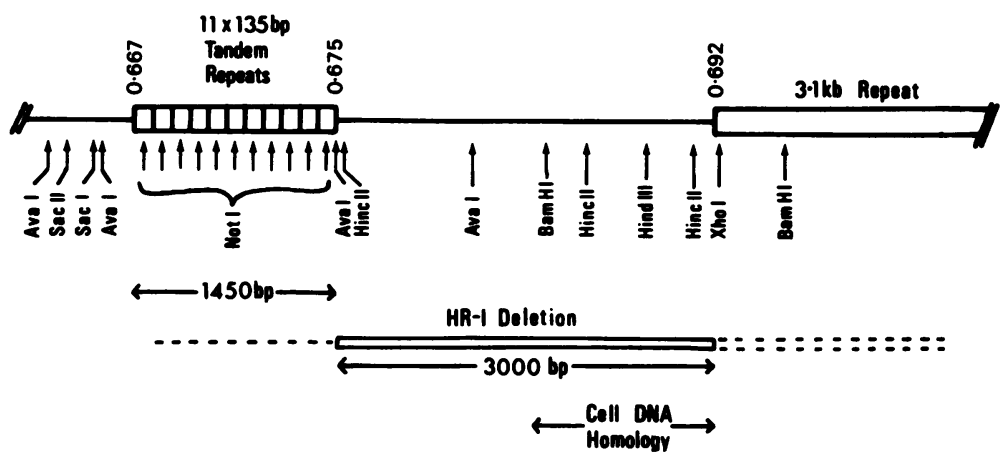

FIG. 9. Map location of the 135-bp Not I repeats in B95-8 DNA relative to the HR-1 deletion and 3.1-kb large internal repeats. (a) Comparison of the total size and structure of EBV(B95-8) and EBV(HR-1) genomes. The exact number of 3.1-kb repeat units missing in the HR-1 DNA is not known. In the electron microscope measurements on partially denatured molecules by Bornkamm et al. (2), the HR-1 DNA molecules can be interpreted as having four fewer repeats than B95-8. On the other hand, Rymo and Forsblum (20) suggest a difference of six copies, with HR-1 retaining only three or four. We have arbitrarily drawn six repeats in HR-1 DNA. (b) Expanded view of the region of the $U_{L}$ side of the 3.1-kb repeats in EBV(B95-8) that is implicated in transformation of B-lymphocytes (7). Only the position of unique-sequence DNA deleted in the HR-1 nontransforming isolate is depicted. The boundaries of the deletion within the Not $\mathrm{I}$ repeats and the 3.1-kb internal repeat sequence cluster cannot be determined by the procedures used in this work.

peat-sequence DNA or 1.6 repeat units. Thus, the 3.1-kb repeat unit cluster in B95-8 contains 12.6 tandemly duplicated copies of the repeat unit. Although the total number of $3.1-\mathrm{kb}$ repeats varies from isolate to isolate, both of the isolates that we have studied in detail contain a nonintegral repeat unit number (12.6 in the case of B95-8 and 7.6 in the case of EBV [MCUV]; 10), with similar locations for the repeat-unique sequence boundaries. Whether the presence of this extra $60 \%$ of a repeat unit is important for proper gene expression from (or maintenance of) the repeat DNA cluster is unclear, but the fact that this feature is retained even when the total repeat unit number varies is suggestive of a functional significance.

EBV(HR-1) virus lacks the ability to transform lymphocytes, and this loss of "immortalizing" function appears to correlate with a characteristic deletion in the $U_{L}$ segment of the HR-1 genome. This HR-1 deletion terminates on one side within the $3.1-\mathrm{kb}$ large internal repeat se- quences, reducing the number of repeat unit copies from 12.6 in B95-8 to between 3 and 6 in HR-1 and possibly also altering the overall structure of the BamHI repeat complex. In addition, the deletion removes all unique-sequence DNA from BamHI-Y plus a large portion of the adjacent BamHI-H fragment. We have determined that HR-1 has lost a total of 3,000 bp of singlecopy DNA from $U_{L}$ plus an unknown amount of repeat-sequence DNA and that the deletion is bounded on either side by tandemly repeated sequences. Thus, the deletion eliminates all sequences lying between the 3.1-kb internal repeat cluster and a newly identified but apparently unrelated set of 11 135-bp repeats. We wish to emphasize that our experiments at present provide no information about whether any or all of the NotI repeats remain in HR-1. Since the BamHI-W, $-Y$, and -H fragments are known to be major templates for transcription in EBVtransformed lymphocytes $(13,14)$, the deletion of coding sequences from within this region may 
be sufficient to account for the loss of the transforming function in HR-1 virus.

The viral DNA in and around the HR-1 deletion has a number of unusual features which indicate a complex structural organization. In addition to the 3.1-kb repeats and the newly discovered NotI repeats, there are segments which exhibit homology to either mammalian cell DNA or other portions of the viral genome. The cloned EBV BamHI-Y fragment contains sequences which hybridize with middle repetitive cellular DNA from both human and mouse genomes, and these map within the single-copy viral sequences that are lost in the HR-1 deletion (K. Peden, P. Mounts, and G. Hayward, submitted for publication). Our preliminary mapping data show that the region of BamHI-H which has homology with the "additional" viral DNA at coordinate 0.14 in the W91, AG876, and FF41 isolates $(6,12,17)$ lies adjacent to the NotI repeats but on the opposite side from the deletion. Finally, since both the B95-8 NotI repeats and a nearby region of BamHI-H defined by a 480-bp AvaI fragment fail to form hybrids on filters with homologous B95-8 viral DNA probes, further unusual structural arrangements can be expected.

\section{ACKNOWLEDGMENTS}

We acknowledge the competent technical assistance of Thomas McClintock, Michael McLane, and Judith Wilt and thank Nancy Standish for preparation of the manuscript.

This work was supported by grants to S.D.H. from the American Cancer Society (grants MV59A and MV59B) and to G.S.H. from the National Institutes of Health (Public Health Service grant ROI CA22130).

\section{ADDENDUM IN PROOF}

Nucleotide sequence data indicate that the NotI repeat unit consists of $126 \mathrm{bp}$ and has a base composition of $83 \%$ guanine plus cytosine. Direct mapping of cloned EBV(HR-1) DNA fragments places the boundary of the deleted region between the SacII and SacI sites of EBV(B95-8) BamHI-H (J. Hudewentz, U. K. Freese, U. Zimber, and G. W. Bornkamm, J. Virol., in press; D. Hayward, unpublished data). We thank Georg Bornkamm for exchanging preprints of unpublished work.

\section{LITERATURE CITED}

1. Birnboim, H. C., and J. Doly. 1979. A rapid alkaline extraction procedure for screening recombinant plasmid DNA. Nucleic Acids Res. 7:1513-1523.

2. Bornkamm, G. W., H. Delius, U. Zimber, J. Hudewentz, and M. A. Epstein. 1980. Comparison of Epstein-Barr virus strains of different origin by analysis of the viral DNAs. J. Virol. 35:603-618.

3. Clewell, D. B., and D. R. Helinski. 1969. Supercoiled circular DNA-protein complex in Escherichia coli: purification and induced conversion to an open circular DNA form. Proc. Natl. Acad. Sci. U.S.A. 62:1159-1166.

4. Dambaugh, T., C. Beisel, M. Hummel, W. King, S. Fennewald, A. Cheung, M. Heller, N. Raab-Traub, and E. Kieff. 1980. Epstein-Barr virus DNA. VII. Molecular cloning and detailed mapping of EBV (B95-8) DNA. Proc.
Natl. Acad. Sci. U.S.A. 77:305-309.

5. Delius, H., and G. W. Bornkamm. 1978. Heterogeneity of Epstein-Barr virus. III. Comparison of a transforming and a nontransforming virus by partial denaturation mapping of their DNAs. J. Virol. 27:81-89.

6. Fischer, D. K., G. Miller, L. Gradoville, L. Heston, M. W. Westrate, W. Maris, J. Wright, J. Brandsma, and W. C. Summers. 1981. Genome of mononucleosis Epstein-Barr virus contains DNA fragments previously regarded to be unique to Burkitts lymphoma isolates. Cell 24:543-553.

7. Fresen, K. O., M.-S. Cho, and H. zurHausen. 1980. Recombination between Epstein-Barr virus genomes. Virus in naturally occurring cancers. Cold Spring Harbor Conf. Cell Prolif. 7:35-44.

8. Given, D., and E. Kieff. 1979. DNA of Epstein-Barr virus. VI. Mapping of the internal tandem reiteration. J. Virol. 31:315-324

9. Given, D., D. Yee, K. Griem, and E. Kieff. 1979. DNA of Epstein-Barr virus. V. Direct repeats at the ends of Epstein-Barr virus DNA. J. Virol. 30:852-862.

10. Hayward, S. D., L. Nogee, and G. S. Hayward. 1980. Organization of repeated regions within the Epstein-Barr virus DNA molecule. J. Virol. 33:507-521.

11. Hayward, G. S., and M. G. Smith. 1972. The chromosome of bacteriophage T5. I. Analysis of the single-stranded DNA fragments by agarose gel electrophoresis. J. Mol. Biol. 63:383-395.

12. Heller, M., T. Dambaugh, and E. Kieff. 1981. EpsteinBarr virus DNA. IX. Variation among viral DNAs from producer and nonproducer infected cells. J. Virol. 38:632648.

13. Jones, P. C., G. S. Hayward, and B. Roizman. 1977. Anatomy of herpes simplex virus DNA: VII. Alpha RNA is homologous to noncontiguous sites in both the $L$ and $S$ components of viral DNA. J. Virol. 21:268-276.

14. King, W., A. L. Thomas-Powell, N. Raab-Traub, M. Hawke, and E. Kieff. 1980. Epstein-Barr virus RNA. V. Viral RNA in a restringently infected, growth-transformed cell line. J. Virol. 36:506-518.

15. King, W., V. van Santen, and E. Kieff. 1981. Epstein-Barr virus RNA. VI. Viral RNA in restringently and abortively infected Raji cells. J. Virol. 38:649-660.

16. Kintner, C., and B. Sugden. 1979. The structure of the termini of the DNA of Epstein-Barr virus. Cell 17:661671.

17. Raab-Traub, N., T. Dambaugh, and E. Kieff. 1980. DNA of Epstein-Barr virus. VII. Analysis of molecular epidemiology of the "additional" DNA of two Burkitt tumor isolates of EBV. Cell 22:257-267.

18. Raab-Traub, N., R. Pritchett, and E. Kieff. 1978. DNA of Epstein-Barr virus. III. Identification of restriction enzyme fragments that contain DNA sequences which differ among strains of Epstein-Barr virus. J. Virol. 27:388-398.

19. Rigby, P., M. Dieckmann, C. Rhodes, and P. Berg. 1977. Labeling DNA to high specific activity in vitro by nick translation with DNA polymerase I. J. Mol. Biol. 113:237-252.

20. Rymo, L., and S. Forsblum. 1978. Cleavage of EpsteinBarr virus DNA by restriction endonucleases EcoRI, HindIII and BamI. Nucleic Acids Res. 5:1387-1402.

21. Rymo, L., D. Lindahl, and A. Adams. 1979. Sites of sequence variability in EBV DNA from different sources. Proc. Natl. Acad. Sci. U.S.A. 76:2794-2798.

22. Skare, J., and J. L. Strominger. 1980. Cloning and mapping of BamHI endonuclease fragments of DNA from the transforming B95-8 strain of Epstein-Barr virus. Proc. Natl. Acad. Sci. U.S.A. 77:3860-3864.

23. Smith, H. O., and M. L. Birnstiel. 1976. A simple method for DNA restriction site mapping. Nucleic Acids Res. 3:2387-2398.

24. Southern, E. M. 1975. Detection of specific sequences among DNA fragments separated by gel electrophoresis. J. Mol. Biol. 98:503-517.

25. Sugden, B. 1977. Comparison of Epstein-Barr viral DNAs in Burkitt lymphoma biopsy cells and in cells transformed in vitro. Proc. Natl. Acad. Sci. U.S.A. 74:4651-4655. 